\title{
Growth and Vitamin A Enhancement Effects of Provitamin A $\beta$ - Carotenoid Cassava (Manihot Esculanta Crantz) UMUCASS38 (IITA-TMS-IBAO114121), in the Practical Diets of Fingerling of African Catfish Heterobranchus longifilis
}

\author{
Uchechukwu. D. ENYIDI ${ }^{*}$, Jennifer. NWAHIRI ${ }^{1}$ \\ ${ }^{1}$ Department of Fisheries and Aquatic Resources Management Michael Okpara University of \\ Agriculture Umudike Umuahia Abia State Nigeria.
}

\begin{abstract}
Cassava is the fifth globally most important staple crop but like most plant feed ingredients are deficient in vitamin A (VA). Genetically engineered provitamin A $\beta$-carotene, (proVAC) cassava may be plausible source of vitamin $A$ and energy to those fishes that can tolerate high carbohydrate diet. The $\beta$ carotene in genetically improved cassava root can be converted by fish to vitamin A. We produced five isonitrogenous and isocalorific diets (feed 1 to feed 5 ) with non fermented proVAC cassava and $\beta$-carotene inclusion levels of $F 1,20 \%, 114.6 \mu \mathrm{g} \mathrm{g}^{-1}, F 2,15 \%, 85.95 \mu \mathrm{g} \mathrm{g}^{-1}, F 3,10 \%, 57.3 \mu \mathrm{g} \mathrm{g} \mathrm{g}^{-1}, F 4,5 \%, 28.65 \mu \mathrm{g} g-1$ and F5 $0 \%, 0 \mu \mathrm{g} \mathrm{g}^{-1}$. African catfish Heterobranchus longifilis of average weight $1.69 \pm 0.5 \mathrm{~g}$, were stocked at 10 fish per 15L aquaria in 3 replicates per feed type and fed ad libitum for 10 weeks. The growth and effects of the dietary provitamin A carotene on the fish were examined. Specific growth rate was best for catfish fed F4, 4.95 $\pm 0.10 \%$ day $^{-1}$ and reduced with increasing inclusion of proVAC cassava. The FCR was best and same for those fed $0 \%$ cassava F5, $1.72 \pm 0.06$ and 5\% cassava F4, $1.73 \pm 0.03$, decreasing with reducing inclusion of proVAC cassava. The VA content of the catfish was highest for those fed with $20 \% 114.6 \mu \mathrm{g} \mathrm{g}^{-1}$ proVAC $(F 1)$. Catfish VA content increased with increasing inclusion of proVAC cassava and $\beta$-carotene values of the diets. Gut length significantly reduced with increasing ProVAC cassava. Inclusion of proVAC cassava should not be above $5 \%$ in diets of Heterobranchus longifilis.
\end{abstract}

Keywords: Vitamin A, $\beta$-carotene, cassava, Specific growth rate, bio fortification, African catfish

\section{INTRODUCTION}

The high cost of fishmeal as fish feed ingredient necessitates substitution with plant proteins. Plant ingredients that can be used in fish feed substitution must be available and cost efficient [1] Cassava is one of the main crops in Africa, hence easily available and apart from its binding properties can be a useful source of energy. Plant ingredients that contain carbohydrate are useful as energy sources in fish feed [2 3]. Plant ingredients can be used as source of protein, lipids or energy via carbohydrate $[4,5,6]$. A major setback in using plant ingredients is lack of essential nutrients like amino acids and vitamins [17]. Genetically modified provitamin A cassava has higher vitamin A precursor $\beta$-Carotene than ordinary cassava. Consequently plant ingredients with very high carbohydrates can be suitable as energy source for those fish that tolerate carbohydrate, as well as $\beta$-Carotene. The VA level in fish feed will be enhanced if inclusion of VA precursors ingredient like, maize, provitamin A cassava and palm oil are considered during substitution of fishmeal with plant ingredients.. Fishmeal is a major source of vitamin A $[8,9]$. It could be helpful to source some plant products that can provide the needed VA in fishmeal substituted diets. Cassava (Manihot esculenta Crantz) is known as the fifth globally most important staple crop worldwide but is most important in sub-Saharan nations like Nigeria and Ghana [10, 11, 12]. Nigeria is the largest producer of cassava in the World with over 50 million metric tons with cultivation area of about 3.7 million ha [13]. The cassava root meal is rich in starch but poor in protein and micronutrients like iron, zinc, and provitamin A [14, 15, 16]. The root of cassava contains approximately $90 \%$ carbohydrate dry weight basis and up to $80 \%$ is starch $[5,17]$. Cassava has about $1-3 \%$ protein $[14,18]$. Cassava leave meal is more proteinuos than root meal and Cassava root meal has been used as feed additive in the diets of Nile Tilapia $[19,20]$ and pacu (Piaractus mesopotamicus, [21]. Cassava also contains sucrose, glucose, fructose, and maltose [17]. 
The use of cassava root meal in feeding Nile Tilapia resulted in poor growth [5, 20].Poor growth of fish fed with cassava root meal could be due to poor protein and lipid content. Genetically improved proVAC cassava have not yet been used as fish feed additive. Cassava is deficient in VA. Vitamin A refers to small group of compounds called retinoids, Vitamin A occurs in different forms as, alcohols retinol or as aldehyde [22]. A major problem with use of cassava is the presence toxic cyanogenic glycosides linamarin and lotaustralin [23, 24]. However different processing methods eliminate the toxic substances like solid state fermentation [25], boiling and steaming, [25, 26, 27, 28 29] and wet fermenting [30, 31].

Harvest Plus, which is part of the Consultative Group on Internation Agriculture Research (CGIAR) Program on Agriculture for Nutrition and Health (A4NH) sponsor researches on the use of conventional plant breeding techniques to biofortify cassava $[32,33]$. A ProVAC cassava variety with enhanced higher levels of provitamin A carotenoids (pVAC), precursors of vitamin A, UMUCASS38 (IITA-TMS-IBAO114121) was produced and cultivated at National root crop research institute Umudike Umuahia Nigeria. Several cassava varieties, high in pro-vitamin A content, have been produced and released in Nigeria [32]. The concept behind biofortification of cassava with provitamin A carotenoid $\beta$-carotene is to upset or alleviate vitamin A deficiency suffered by over 25 million African and Asia, women and children inclusive [34,35, 33] .

Provitamin A carotenoids (proVAC) which contains at least one $\beta$-ionone ring can serve as precursors of Vitamin A like retinoids when consumed by animals [36]. The genetically modified, proVAC cassava can supply vitamin A precursor $\beta$-carotene and equally serve as binder in aquafeed. Inclusion of provitamin A cassava in fish feed could have profound effects in elevating the biomass Vitamin A (VA) content of the fish. Excess VA are stored in the liver which has about $90 \%$ of the VA stored [37]. It had been noted that inclusion of fortified cassava in human diets increased the $\beta$-carotene and vitamin A concentrations of American women the TAG-rich plasma [38]. Moreso, vitamin A intake of humans was increased in Philippines by increasing vitamin A intake through biofortification of rice at 8-12 ppm of $\beta$-carotene [39]. Plant based materials roots, leaves and fruits are sources of carotenoids, while cassava leaves and roots in particular have been used as leave meal in fish feed manufacturing [5,40,41]Cassava is used for their energy, small protein, minerals, fiber, vitamins and essential amino acids $[42,43]$. Plant tissue that contains up to $46 \sim 74 \mathrm{IU} \mathrm{g}^{-1}$ of $\beta$-carotene is regarded as source of VA [44]. The vitamin A is an essential micronutrient in fish diets it enhances formation of mucous membranes and prevention of exophthalmia [45]. Vitamin A has also been noted as responsible for gene expression, development, visual adaptation, growth and immune system [46, 47]. The root of cassava contains approximately $90 \%$ carbohydrate dry weight basis and up to $80 \%$ is starch [17]. Biofortified cassava has about $9.5 \mathrm{~g}$ of protein /100g [38]. Cassava meal has been used in feeding Nile tilapia [48, 49, 21], pacu, Piaractus mesopotamicus Padua et al. [21], and milkfish [50].

African catfish $C$. gariepinus utilizes carbohydrate very well [51]. African catfish $H$. longifilis is in the same family Siluridae and class Siluriformes with $C$. gariepinus but does not grow as fast. $H$. longifilis occurs naturally in Nigerian waters and is cherished food fish with firmer flesh than C.gariepinus. Warm freshwater fish can better utilize high carbohydrate feed than cold water fish or marine fish [52]. The quantity of carbohydrate in feed mix affects the HSI of the fish [53]. Vitamins are micro nutrients that are needed in small quantities but their deficiency leads to lack of appetite in fishes [54], impaired growth, poor bone development, hematological problems [55, 56, 57,9] . Deficiency of vitamin A has been noted to affect gut morphology by reducing intestinal fold height in juvenile Jian carp, Cyprinus carpio var [58]. Lack of vitamin A in the diets of Oreochromis niloticus had been associated with depigmentation, absence of mucus secretion in mucous layer and infestation [54]. Deficiency of Vit. A would as well lead to exophthalmia and blindness, erratic swimming, hemorrhage in the fin base and internal hemorrhage [55]. Conversely excess VA can lead to hypervitaminosis and cause deformed vertebral column, jaw and fin structures [54, 57, 59, 60],.

This research is aimed at finding the effects of inclusion levels of proVAC cassava in the diets of African catfish $H$. longifilis on the growth, nutrient utilization and body vitamin A content. ProVAC cassava is a novel cassava variety and higher in protein than ordinary cassava. ProVAC cassava also have $\beta$-carotene which is usually deficient in almost all cassava varieties. The research also seeks to find possible effects of proVAC cassava on the gut morphology. 


\section{MATERIALS AND MeTHODS}

\section{Processing of proVAC Cassava}

ProVAC cassava UMUCASS38 (IITA-TMS-IBAO114121) roots were harvested from the farms of National Roots Crops Research Institute (NRCRI) Umudike, Umuahia, Nigeria. The roots were peeled manually and washed with water in a shaded place. The roots were cut into chips and soaked in water for $2 \mathrm{~h}$. Then they were washed with clean water. The chips were dried to constant weight with an electric oven (Hitachi Company Japan) set at constant temperature of $45^{\circ} \mathrm{C}$. Dried pro vitamin A carotenoid (proVAC) cassava pellets were milled into fine flour in a dark room using a locally fabricated milling machine. The milled flour was packed in a black colored polyethylene bag and stored in a cool dry place.

\section{Preparation of different experimental diets}

Five experimental diets were made to vary in inclusion of pro vit A carotenoid cassava (proVAC) (UMUCASS38) IITA-TMS-IBAO114121. The percentage inclusion of the proVAC cassava per treatment diets were as follows; Feed 1, F1, 20\%; feed 2, F2, 15\%; feed 3, F3, 10\%, feed 4, F4 5\% and feed 5, F5, 0\%. Soybean meal, fish meal and PBP were used as the major sources of protein and included with no significant difference in all diets (Table 1). Corn meal, lysine, methionine, palm oil, vit $\mathrm{C}$, and vitamin premix were also added. In making the experimental diets, each of the feed ingredients as stipulated in table 1, were weighed and mixed using an electric mixer (Kenwood Chef Mixer). Approximately $150 \mathrm{mls}$ of water was added to each of the feed mixes $(1 \mathrm{~kg})$. The mixed dough was preconditioned at $100^{\circ} \mathrm{C}$ in a pressurized cooking chamber and the resulting dough was pelleted with $1 \mathrm{~mm}$ die. The diets were made to be isonitrogenous approximately $31 \pm 1.8 \%$ protein and isocalorific. Pelleted diets were dried using a thermocool microwave desiccators. Feeds were dried at a controlled temperature of $45^{\circ} \mathrm{C}$ till approximately $10 \%$ moisture content was achieved. The dried diets were placed in well labeled polyethelene airtight bags and stored at room temperature till used. The feed composition table and proximate composition of feed are shown in Table 1 . The proximate composition of the provitamin A cassava is shown in Table 2.

\section{Experimental design}

The research is designed using completely randomized design (CRD). There were three replicates of the experimental diets and the control. There were 16 rectangular plastic aquariums of dimensions width $50 \mathrm{~cm}$, length $80 \mathrm{~cm}$ and height $30 \mathrm{~cm}$. The plastic aquaria were screened with mosquito net to prevent fish from jumping out. The aquariums water was changed daily by siphoning out $3 / 4$ of the water and replacing it with clean pure water. Water supply was from the borehole overhead water reservoir of the wet laboratory, FISHARM department Michael Okpara University of Agriculture Umudike Umuahia, Abia State Nigeria.

\section{Experimental fish}

Fingerlings of African catfish $H$. longifilis of 7 weeks old and average weight $1.69 \pm 0.5 \mathrm{~g}$ were obtained from a commercial fish farm within Abia State Nigeria. The catfish were transported in oxygen filled water nylon bags to the wet laboratory of FISHARM Department, Michael Okpara University of Agriculture. The fish were acclimatized for 12 days during which time they were fed with $35 \%$ protein commercial diet. The catfish were sorted and stocked at density of 10 fingerlings per treatment feed aquaria. There were three replicate aquariums per feed type.

\section{Experimental procedure}

The initial weights of the fish were taken with electronic balance at the beginning of the experiment. The fish were subjected to a L12:D12 photoperiod. The experimental set up was covered with opaque screen and light intensity was maintained at c.10 lux (HD 9221 lux meter, Delta OHM, Italy). The catfish were hand fed to satiation three times daily. Feeding was done after cleaning the tank in the morning 08-09 hours, afternoon 13-14 hours and in the evening 18-19 hours. The catfish were not fed for 16 hours before weighing. The fish were weighed together to check for weight increase every two weeks. Catfish culturing lasted for a period of 10 weeks. At the end of the experiment the catfish were 
weighed in batches per treatment and 15 fish per treatment feed type ( 5 from each of the 3 replicates) were separated for analysis. The separated fish were weighed, dissected and used for anatomical analysis. The liver and the visceral fat contents of the fish were extracted, weighed and generated data were recorded according to the treatment. The data were used in calculating the hepatosomatic index and the visceral fat somatic index. The fish samples used for vitamin A determination were entirely homogenized per replicate aquaria using a meat blender.

\section{Chemical analysis}

The chemical analysis were done at National Root Crop Research Institute Umudike, Umuahia Abia State. The research Institute is adjacent to Michael Okpara University of Agriculture Umudike Umuahia Nigeria.

Proximate analyses of diets

Moisture content of the feeds was measured by oven drying feed samples at $105^{\circ} \mathrm{C}$ to a constant weight. Dried fish samples were used for other proximate analyses. Ash content was measured by incineration samples within a muffle furnace at $550^{\circ} \mathrm{C}$ for $24 \mathrm{hrs}$. Lipids contents of the feed and the fish were analyzed using a modified chloroform methanol method as described in Enyidi et al.[7], after modified methods of Parrish, [61] and Kainz [62]. Lipids in the samples were extracted twice with 2:1 chloroform: methanol mixture. Lipid extraction was Whole body protein was analyzed by Kjeldahl method, using Tecator Kjeltech model 1002 (Tecator, Kjeltect, Höganäs, Sweden). Protein $\%$ was expressed as $\% \mathrm{~N} \times 6.25$. Phytic acid analyses were measured according to Wheeler and [63].

\section{Determination of vitamin A}

Vitamin A content of the fish and feed were determined using methods stipulated in AOAC official methods 2001 revised in 2007. About 5g of dried samples and standards were saponified in basic ethanol-water solution, neutralized, and diluted. As a consequence the fats are converted to fatty acids, and retinyl esters get converted to retinol and the corresponding fatty acids. Furthermore the extract was cleaned-up with a C18 cartridge and vitamin A was concentrated eluting with a smaller volume of alcohol isopropanol than the aliquot taken to clean. Retinol is quantified in an LC system, using UV detection at $326 \mathrm{~nm}$. The vitamin A concentration was estimated by comparison of peak heights or peak areas of retinol in test samples with those of standards

The quantity of Vitamin $\mathrm{A},(\mathrm{VA})$ in $\mu \mathrm{g} \mathrm{g}^{-1}$ (as retinol)=

$$
\mathrm{VA}=\underline{\text { RFA } \mathrm{x} \text { PHsam } \mathrm{x} 100}
$$

$\mathrm{W}$

Where: Response factor for vitamin A (RFA)

PHsam $=$ total sample peak height or area of all-trans

$100=$ dilution volume of sample

$\mathrm{w}=$ weight of sample in $\mathrm{g}$

Determination of hydrogen cyanide

The hydrogen cyanide content of proVAC cassava was determined using the combined picrate test methods and spectrophotometer methods Fukushima et al. [64].Fresh root of proVAC cassava was peeled and 1-2 mm thick piece of the cassava was cut across the midsection of the root. The cut portion was weighed to be $100 \mathrm{mg}$ by weighing in electronic balance. A round paper disc containing phosphate buffer solution at $\mathrm{pH} 6$ was placed at the bottom of the round bottom plastic flask. The 100 $\mathrm{mg}$ sector of cassava root was placed on top of the paper. About $0.5 \mathrm{ml}$ of clean water was added using plastic pipette.

\section{Making of phosphate buffer and picrate paper}

The phosphate buffer was made by adding $750 \mathrm{ml}$ of fresh water to $80 \mathrm{ml}$ of concentrated phosphoric acid $\left(88 \% \mathrm{H}_{3} \mathrm{PO}_{4}\right)$. Approximately $100 \mathrm{~g}$ of $(\mathrm{NaOH})$ sodium hydroxide pellet were dissolved in water and made up to $250 \mathrm{ml}$ making $10 \mathrm{M} \mathrm{NaOH}$. This sodium hydroxide solution was gradually was added to the phosphoric acid solution slowly with stirring. The $\mathrm{pH}$ was regularly measured with a hand held $\mathrm{pH}$ meter till it reached $\mathrm{pH} 6$. Picrate paper was produced by weighing $1.4 \mathrm{~g}$ of moist picric acid to 
which was added $100 \mathrm{ml}$ of sodium carbonate solution that was produced by dissolution of $2.5 \mathrm{~g}$ of sodium carbonate in $100 \mathrm{ml}$ of water. Filter paper was cut to10 $\mathrm{cm} \mathrm{x} 10 \mathrm{~cm}^{2}$ and inserted into the picrate solution for $20 \mathrm{sec}$ and dry in air. Picrate paper became yellow from the solution and was used for the cyanide analysis.

The picrate paper was attached to a plastic strip and placed into the round bottom plastic flask (containing the cassava strip) without touching the liquid. The cover was tightly closed and allowed to stand in room temperature. Another similar sample was produced but without cassava strip but with standard pink linamarin paper. The bottles were allowed to stand for 16-24h. The color of the paper matched and read against color chart provided by maker of the test kit. The control was 0 and gave 50 color. The picrate paper was removed and put in a test tube and $5 \mathrm{ml}$ of water to it to dissolve the cyanogen from the paper by gently swirling. The blank paper from control was also removed and placed in a test tube with water. After 30min the absorbance of the solution was taken using spectrophotometer at $510 \mathrm{~nm}$. Total cyanide was measured as $396 \mathrm{X}$ absorbance. The cyanide content of the cassava is recorded in Table 3.

\section{Gut length analysis and water quality test}

At the end of the experiment catfish were dissected with a dissecting scalpel from esophagus to the anus. Dissection was carefully done to ensure that internal organs were not damaged. Fat and blood attached to the gut length were carefully removed from the esophagus to anus. The whole line of gut from esophagus to the anus was extracted and weighed. The length of the gut were measured. The data were recorded according to each of the three replicate treatment diets.

Water quality parameters such as temperature, $\mathrm{pH}$, and dissolved oxygen were taken daily. Temperature was measured using mercury in-glass thermometer, $\mathrm{pH}$ was measured using $\mathrm{pH}$ meter and dissolved oxygen $\left(\mathrm{DO}_{2}\right)$ was measured using Winkler's method. The average $\mathrm{pH}$ was noted to be $6.7 \pm 0.09$, while the temperature was $27 \pm 0.06{ }^{\circ} \mathrm{C}$. Dissolved oxygen $\mathrm{DO}_{2}$ was $5.2 \pm 0.02 \mathrm{mg} / \mathrm{l}$ (Table $3)$.

Table 1. Feed composition and proximate analysis of feeds used in feeding fingerlings of H. Longifilis fed with feeds varying in composition of pro vitamin A cassava (ProVAC cassava)

\begin{tabular}{|c|c|c|c|c|c|}
\hline Ingredients & F1 & $\mathrm{F} 2$ & F3 & $\mathrm{F} 4$ & F5 \\
\hline Fish Fishmeal & 25 & 25 & 25 & 25 & 25 \\
\hline Soybean & 40 & 40 & 40 & 40 & 40 \\
\hline ProVAC & 20 & 15 & 10 & 5 & 0 \\
\hline PBP & 8 & 10 & 10 & 10 & 10 \\
\hline Corn meal & 2 & 5 & 10 & 15 & 20 \\
\hline Lysine & 1 & 1 & 1 & 1 & 1 \\
\hline Methionine & 1 & 1 & 1 & 1 & 1 \\
\hline Vitamin C & 1 & 1 & 1 & 1 & 1 \\
\hline Vitamin /premix ${ }^{\mathrm{a}}$ & 1 & 1 & 1 & 1 & 1 \\
\hline Palm oil & 1 & 1 & 1 & 1 & 1 \\
\hline Total & 100 & 100 & 100 & 100 & 100 \\
\hline \multicolumn{6}{|c|}{ Proximate composition } \\
\hline Crude Protein & 30.2 & 30.64 & 31.98 & 31.07 & 32.78 \\
\hline Crude Lipids & 6.68 & 6.81 & 6.18 & 6.70 & 6.87 \\
\hline Starch & 48.02 & 47.86 & 46.04 & 43.03 & 41.06 \\
\hline Dry matter & 93.63 & 94.46 & 93.19 & 93.22 & 92.81 \\
\hline Crude fiber & 4.82 & 5.9 & 7.34 & 6.45 & 5.29 \\
\hline Ash & 7.84 & 8.27 & 8.04 & 7.98 & 7.2 \\
\hline Moisture & 6.37 & 5.54 & 6.81 & 6.78 & 7.19 \\
\hline Phytate & 0.37 & 0.62 & 0.5 & 0.44 & 0.61 \\
\hline$\beta$-carotenoid & 114.6 & 85.95 & 57.3 & 28.65 & 0 \\
\hline
\end{tabular}

Where proVAC is provitamin A cassava, PBP is poultry byproduct. The following vitamins premix were added to supply the following $\mathrm{Kg}^{-1}$ diet: cholecalciferol, $1300 \mathrm{IU}$; all-race- $\alpha$-tocopheryl acetate, $140 \mathrm{IU}$; menadione sodium bisulfite, $12 \mathrm{mg}$; thiamin HCL, $8 \mathrm{mg}$; riboflavin, $16 \mathrm{mg}$; calcium d-pantothenate, $17 \mathrm{mg}$; biotin, $0.2 \mathrm{mg}$; folic acid, $5 \mathrm{mg}$; vitamin B12, 0.02, niacin, $40 \mathrm{mg}$; pyridoxine $\mathrm{HCl}, 16 \mathrm{mg}$; ascorbic acid (Stay C), $80 \mathrm{mg}$. 
Mineral premix were magnesium phosphate, $5000 \mathrm{mg}$, potassium carbonate, $400 \mathrm{mg}$, manganous sulfate, 10; ferrous sulfate, $5 \mathrm{mg}$; zinc sulfate, $80 \mathrm{mg}$.

Table 2 . Proximate composition of proVAC cassava Used in compounding feed for African catfish H. longifilis

\begin{tabular}{|l|l|}
\hline PARAMETERS & VALUES \\
\hline Crude protein $(\%)$ & 2.07 \\
\hline Starch $(\%)$ & 81.05 \\
\hline Lipids $(\%)$ & 2.73 \\
\hline Vit A $\left(\mu \mathrm{g}^{-} \mathrm{g}^{-1}\right)$ & 573.00 \\
\hline Cyanide $\%$ & 3.08 \\
\hline Ash \% & 2.06 \\
\hline Moisture \% & 8.84 \\
\hline Dry matter \% & 91.16 \\
\hline
\end{tabular}

Table 3. Physico chemical parameters of aquarium water used for culturing African catfish Heterobranchus longifilis fed with pro VA cassava feeds for 10 weeks

\begin{tabular}{|l|l|l|l|l|l|}
\hline & & & Feeds & & \\
\hline Parameters & F1 & F2 & F3 & F4 & F5 \\
\hline Oxygen $(\mathrm{mg} / \mathrm{l})$ & $5.2 \pm 0.01^{\mathrm{ns}}$ & $5.2 \pm 0.02^{\mathrm{ns}}$ & $5.1 \pm 0.06^{\mathrm{ns}}$ & $5.4 \pm 0.06^{\mathrm{ns}}$ & $5.2 \pm 0.02^{\mathrm{ns}}$ \\
\hline $\mathrm{pH}$ & $6.7 \pm 0.03^{\mathrm{ns}}$ & $6.7 \pm 0.09^{\mathrm{ns}}$ & $6.5 \pm 0.02^{\mathrm{ns}}$ & $6.8 \pm 0.05^{\mathrm{ns}}$ & $6.8 \pm 0.08^{\mathrm{ns}}$ \\
\hline Temp $\left({ }^{\circ} \mathrm{C}\right)$ & $27.8 \pm 0.06^{\mathrm{ns}}$ & $27.9 \pm 0.02^{\mathrm{ns}}$ & $28.0 \pm 0.05^{\mathrm{ns}}$ & $27.6 \pm 0.05^{\mathrm{ns}}$ & $28 \pm 0.07^{\mathrm{ns}}$ \\
\hline Turbidity (NTU) & $2.1 \pm 0.02^{\mathrm{a}}$ & $3.0 \pm 0.04^{\mathrm{b}}$ & $2.9 \pm 0.03^{\mathrm{b}}$ & $2.0 \pm 0.03^{\mathrm{a}}$ & $3 \pm 0.06^{\mathrm{b}}$ \\
\hline
\end{tabular}

Calculations and statistical analyses

Specific growth rate (SGR, \%/ day) was determined as:

$\mathrm{SGR}=100 \times(\mathrm{Ln}$ final weight $(\mathrm{g})-\mathrm{Ln}$ initial weight $(\mathrm{g})) /($ period in days $)$

Feed conversion ratio $(\mathrm{FCR})=$ feed fed $(\mathrm{g}) /$ weight gain $(\mathrm{g})$

Protein efficiency ratio $(\mathrm{PER})=$ weight gain $(\mathrm{g}) * \operatorname{protein}^{\mathrm{intake}} \mathrm{p}^{-1}(\mathrm{~g})$

Survival $(\%)=100 \times$ (final number)/ (initial number)

Weight Gain $(\mathrm{MWG})=\mathrm{W}_{2}-\mathrm{W}_{1}$

Where $\mathrm{W}_{2}=$ Final weight gained

$$
\mathrm{W}_{1}=\text { Initial weight gained }
$$

(e) Percentage Survival

$$
=\text { Initial number }- \text { final number } \mathrm{X} 100
$$

Hepatosomatic index $(\mathrm{HSI})=100 *$ liver weight $(\mathrm{g}) *$ fish weight $(\mathrm{g})^{-1}$

Peritoneal fat somatic index $(\mathrm{FSI})=100 *$ intraperitoneal fat $(\mathrm{g}) *$ fish weight $(\mathrm{g})^{-1}$

The ash \% was weight of ash/weight of sample*100

Results data was analyzed using one way analysis of variance (ANOVA). Fishers least significant difference (FLSD) 0.05 was used in separating possible significant differences in treatment means. Statistical package SPSS 14.0 used for analyses.

\section{RESUltS}

African catfish $H$. longifilis accepted the experimental diets and grew with the optimal specific growth rate SGR of $4.95 \pm 0.10 \%$ day $^{-1}$ by those fed with (F4) (5\% proVAC cassava). The catfish fed with $0 \%$ proVAC cassava F5, had the SGR of $4.80 \pm 0.47 \%$ day $^{-1}$ but this was significantly lower than those fed 5\% proVAC feed (F4) (P>0.05) (Table 4). The catfish that was fed with highest inclusion of proVAC cassava (20\%) F1, had low SGR $3.56 \pm 0.30 \%$ day $^{-1}$ but those fed with $10 \%$ cassava were similar to F1, SGR $3.03 \pm 0.68(\mathrm{P}>0.05)$. Generally the SGR of the catfish was decreasing with increasing dietary inclusion of proVAC cassava (Table 4).

The food conversion ratio (FCR) of the catfish was lowest and not significantly different $(\mathrm{P}>0.05)$ for those fed with feed 4, $1.72 \pm 0.06$ and feed 5, $1.73 \pm 0.03$. Feed conversion ratio of the catfish increased with the dietary increasing inclusion of proVAC cassava (Table 4, Fig 1). There was no significant difference $(\mathrm{P}>0.05)$ between the FCR of catfish fed with F1 and F2. However the catfish FCR of F4 and F5 were significantly better than F1 and F2 $(\mathrm{P}<0.05)($ Table 4). 
The catfish fed with feed $4 \mathrm{~F} 4$ had the highest average weight gain of $3.32 \pm 0.22 \mathrm{~g}$ which was not significantly different from the final weight of the catfish fed F5, $3.31 \pm 0.16 \mathrm{~g}(\mathrm{P}>0.05)$. There were significant difference in the weight gain of the fish fed with F1 and F3 $(\mathrm{P}<0.05)$. Average weight gain for the catfish fed with F1, $1.23 \pm 0.67 \mathrm{~g}$ and F3, 2.03 $\pm 0.39 \mathrm{~g}(\mathrm{P}>0.05)$ (Fig 2). The catfish fed with feed F3 had low average weight gain but during the experiment there were parasitic infections noticed on catfish in two replicate aquariums fed with fed F3. The weight gain seems to be increasing with decreasing inclusion of proVAC cassava. The weight gains of the catfish per treatment feed followed similar trend as the final weight. The catfish fed with feed 4 and F5 made the highest weight of $5.00 \pm 0.04 \mathrm{~g}$ and $5.12 \pm 0.03 \mathrm{~g}$.

Protein efficiency ratio was highest for the catfish fed with feed 4 and feed 5 . There was no significant differences between the PER of F4 $1.03 \pm 0.04$ and F5 0.91 \pm 0.07 (P>0.05). The PER of F4 and F5 was higher than those of F2 and F1 $(\mathrm{P}<0.05)$. The catfish PER was however similar those fed with F4 and F5 (P>0.05) (Table 4).

The hepatosomatic index (HSI) of the catfish was highest for those fed with Feed $20 \%$ proVAC cassava inclusion diet $(\mathrm{F} 1,1.71 \pm 0.39)$ followed by those fed with $15 \%$ proVAC cassava diet $(\mathrm{F} 2$, $1.16 \pm 0.90)$. However there was significant differences between HSI of catfish fed with F1 and those with F2 p<0.05. The HSI of catfish fed with F2 was significantly higher than those fed with F4 $(\mathrm{P}<0.05)$ (Table 4$)$. The catfish fed with $20 \%$ proVAC cassava diets had HSI of $1.71 \pm 0.39$ which is not different $(\mathrm{P}>0.05)$ from HSI of those fed with F5 $(0.69 \pm 0.54)$.

The viscerosomatic index measure the fat deposit in the visceral region of the fish in relation to the body weight. Viscerosomatic fat index of the catfish was highest for the catfish fed with feeds F2 $0.09 \pm 0.90$ and F4. $0.09 \pm 0.03$. The viscerosomatic index of feed 3 fed catfish was least of all treatment feeds $(\mathrm{P}<0.05)$. The viscerosomatic index of the catfish fed with F1 was lower than those fed with F2 but not significantly different from those fed with F5 (P>0.05). Survival of the catfish was best for those fed with F1, F4 and F5 without any difference ( $\mathrm{P}>0.05)$, However the least survival was from the catfish fed with F3.

The biomass vitamin A content of the fish was positively correlated to the inclusion levels of proVAC cassava in the treatment diets $\left(\mathrm{R}^{2}=0.993\right)$ (Fig 3$)$. The catfish fed with $20 \%$ proVAC cassava diet $\mathrm{F} 1$, had the highest vitamin A content of $541.12 \pm 1.32 \mu \mathrm{g} \mathrm{g}^{-1}$ this was significant $(\mathrm{P}<0.05)$. The catfish somatic vitamin A content for those catfish fed with diet F2 was 528.82 $\pm 1.42 \mu \mathrm{g} \mathrm{g}^{-1}$, this was lower than those of F1 $(\mathrm{P}<0.05)$. The vitamin A content of catfish fed with F4 was significantly higher than those fed with F5 (P<0.05). Treatment feed 5 (F5) had $0 \%$ proVAC cassava content and the catfish fed with it had significantly lowest content of vitamin A. $38.57 \pm 6.9 \mu \mathrm{g} \mathrm{g}^{-1}$. The initial VA content of the catfish after acclimatization was $30.07 \pm 0.03 \mu \mathrm{g} \mathrm{g}^{-1}$.

We noticed that the gut length of the catfish was affected by inclusion of proVAC cassava in diet (Fig 4 and Fig 5). There were reduction in the gut length as proVAC was increased in the diets (Fig 4). There was also decrease as the quantity of provitamin A precursor $\beta$-carotenoids were increased in the diets (Fig 5).

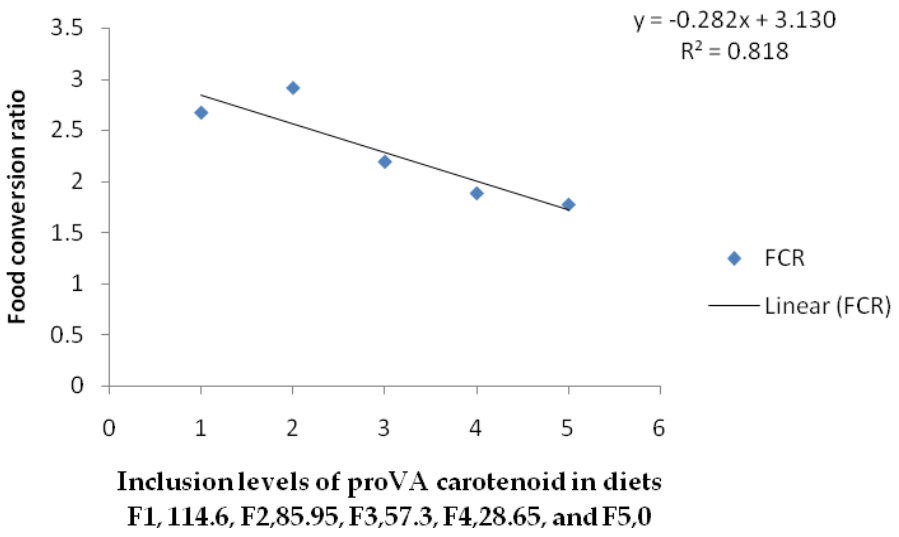

Figure 1. Effects of inclusion levels of provitamin A $\beta$-carotenoid in five isonitrogenous and isocalorific diets F1 to $F 5$ on the feed conversion ratio (FCR) of H. longifilis fed for 10weeks 


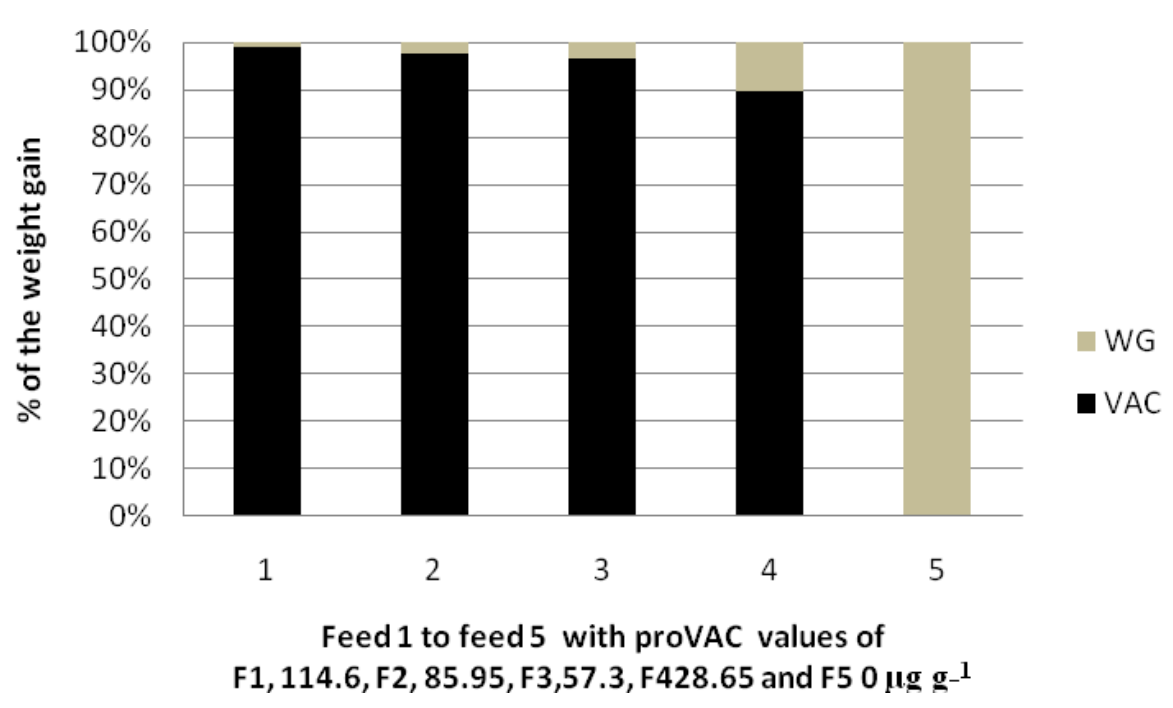

Figure 2. The effects of inclusion of proVAC cassava from $0 \%$ to $20 \%$ in the diets of African catfish $\mathrm{H}$. longifilis on the weight gain after 10 weeks feeding

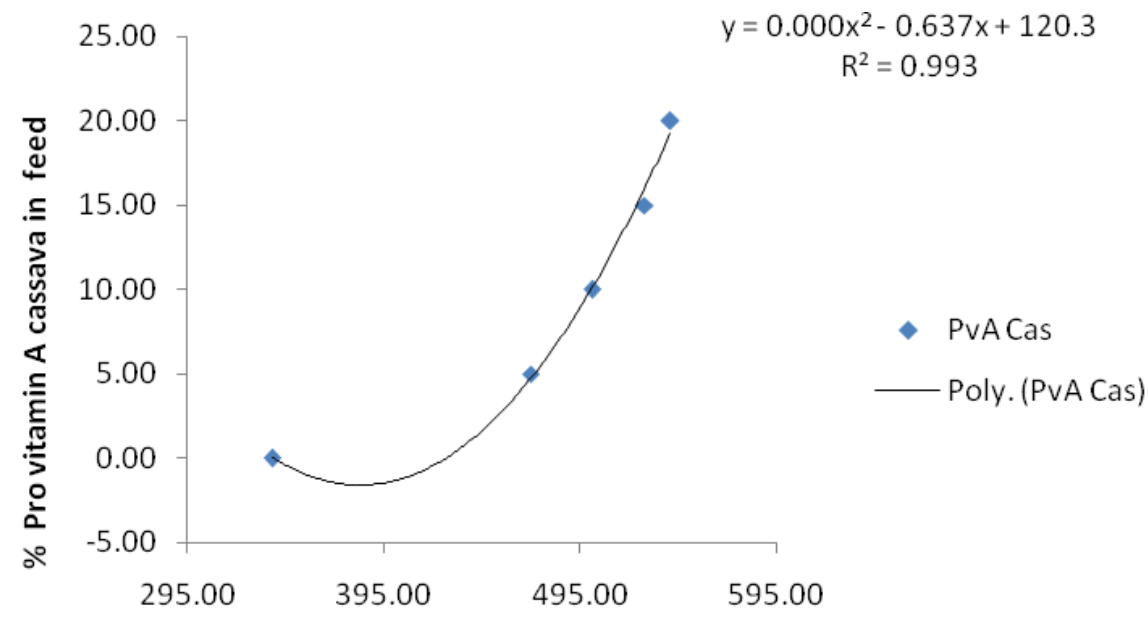

Vitamin A content of catfish after feeding

Figure3. The effects of five isonitrogenous and isocalorific diets with increasing inclusion of proVAC cassava on the vitamin A content of the catfish African catfish H. longifilis fed for 10 Weeks

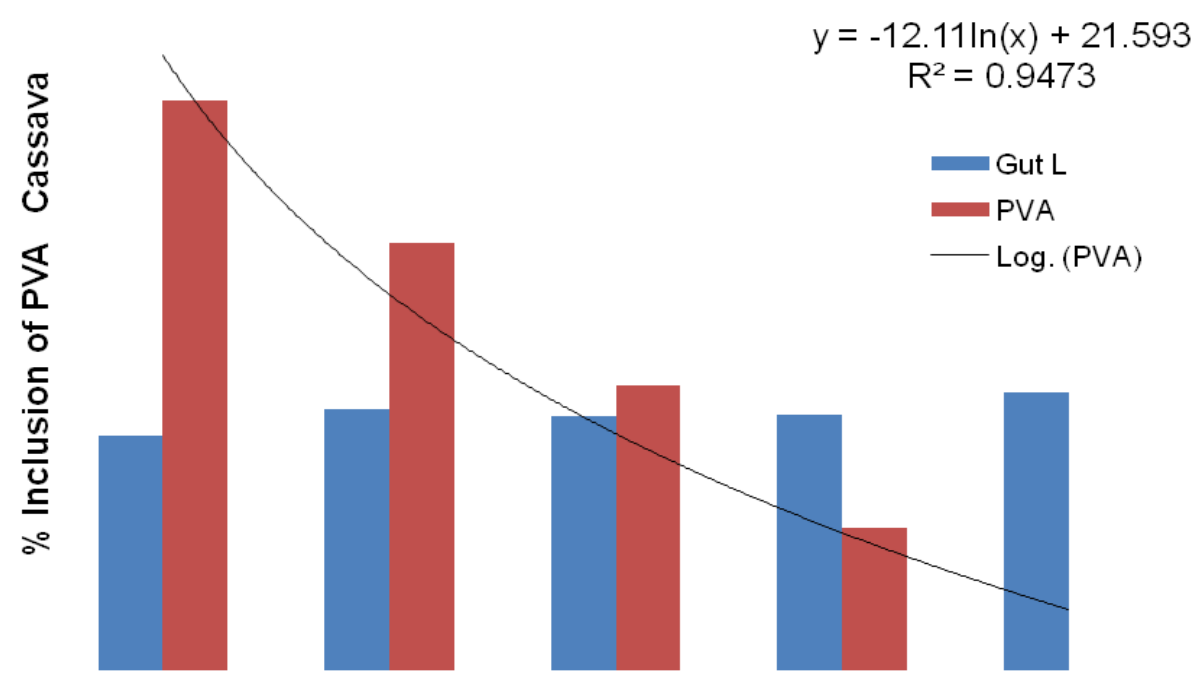

Gut lenght of African catfish H.longifilis fed pro vit $A$ cassava based diets

Figure 4. Effects of 0-20\% provitamin A cassava inclusion in diets of African catfish H. longifilis on the gut length of the fish after 10 weeks feeding 


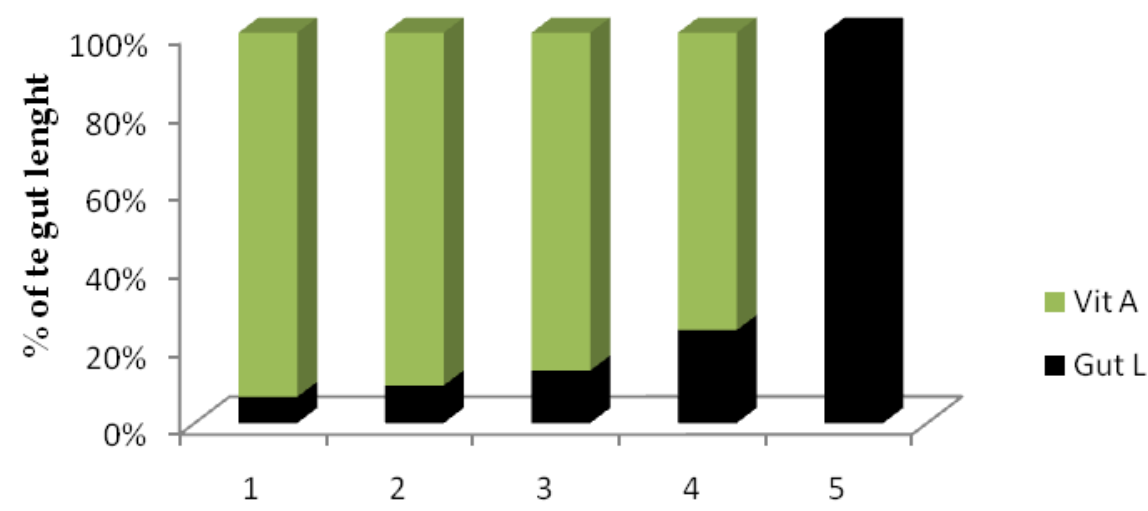

Five diets of $\beta$-carotene content $\mathrm{F1}, 114.6, \mathrm{~F} 2$ $85.95, \mathrm{F3}, 57.30, \mathrm{~F} 4,28.65$ and $\mathrm{F5}, 0$, fed to fingerling H.longifilis

Figure 5. Effects of $\beta$-carotenoid contents of diets varying 0-20\% non fermented proVAC cassava inclusion on the gut length of African catfish $\mathrm{H}$. longifilis after 10 weeks feeding.

Table 4 . Growth and nutrient utilization and gut morphology effects of varying percentage (25-0\%) inclusion of proVAC cassava UMUCASS38 in the diets of African catfish $\mathrm{H}$. longifilis fed for 10 weeks

\begin{tabular}{|l|l|l|l|l|l|}
\hline & & & FEEDS & \\
\hline Parameters & F1 $20 \%)$ & F2 $(15 \%)$ & F3 $(10 \%)$ & F4 $(5 \%)$ & F5 $(0 \%)$ \\
\hline Ini avWt & $1.62 \pm 0.02^{\mathrm{ns}}$ & $1.68 \pm 0.05^{\mathrm{ns}}$ & $1.74 \pm 0.08^{\mathrm{ns}}$ & $1.68 \pm 0.05^{\mathrm{ns}}$ & $1.81 \pm 0.06^{\mathrm{ns}}$ \\
\hline Final av Wt & $2.85 \pm 0.01^{\mathrm{c}}$ & $3.74 \pm 0.03^{\mathrm{b}}$ & $3.77 \pm 0.01^{\mathrm{c}}$ & $5.00 \pm 0.04^{\mathrm{a}}$ & $5.12 \pm 0.03^{\mathrm{a}}$ \\
\hline Wt gain & $1.23 \pm 0.67^{\mathrm{c}}$ & $2.06 \pm 0.84^{\mathrm{b}}$ & $2.03 \pm 0.39^{\mathrm{c}}$ & $3.32 \pm 0.22^{\mathrm{a}}$ & $3.31 \pm 0.16^{\mathrm{a}}$ \\
\hline SGR & $3.03 \pm 0.30^{\mathrm{cd}}$ & $3.56 \pm 0.68^{\mathrm{d}}$ & $3.17 \pm 1.76^{\mathrm{d}}$ & $4.95 \pm 0.10^{\mathrm{a}}$ & $4.80 \pm 0.47^{\mathrm{b}}$ \\
\hline FCR & $2.42 \pm 0.03^{\mathrm{bc}}$ & $2.30 \pm 0.02^{\mathrm{c}}$ & $2.31 \pm 0.05^{\mathrm{b}}$ & $1.73 \pm 0.03^{\mathrm{a}}$ & $1.72 \pm 0.06^{\mathrm{a}}$ \\
\hline PER & $0.41 \pm 0.05^{\mathrm{b}}$ & $0.44 \pm 0.07^{\mathrm{b}}$ & $0.14 \pm 0.05^{\mathrm{c}}$ & $1.03 \pm 0.04^{\mathrm{a}}$ & $0.91 \pm 0.07^{\mathrm{a}}$ \\
\hline VSI & $0.05 \pm 0.86^{\mathrm{ab}}$ & $0.09 \pm 0.90^{\mathrm{a}}$ & $0.01 \pm 0.01^{\mathrm{b}}$ & $0.09 \pm 0.03^{\mathrm{a}}$ & $0.07 \pm 0.03^{\mathrm{a}}$ \\
\hline HSI & $1.71 \pm 0.39^{\mathrm{a}}$ & $1.16 \pm 0.90^{\mathrm{b}}$ & $0.32 \pm 0.01^{\mathrm{c}}$ & $0.46 \pm 0.27^{\mathrm{b}}$ & $0.39 \pm 0.54^{\mathrm{c}}$ \\
\hline VA in fish & $541.12 \pm 1.32^{\mathrm{a}}$ & $528.82 \pm 1.42^{\mathrm{a}}$ & $501.74 \pm 2.09^{\mathrm{b}}$ & $470.14 \pm 5.27^{\mathrm{c}}$ & $38.57 \pm 6.9^{\mathrm{d}}$ \\
\hline Survival & $100^{\mathrm{a}}$ & $73^{\mathrm{b}}$ & $36.67^{\mathrm{c}}$ & $100^{\mathrm{a}}$ & $93.33^{\mathrm{a}}$ \\
\hline
\end{tabular}

Values in the same row, not having the same superscript are statistically significantly different $(\mathrm{P}<0.05)$. VA in $\mu \mathrm{g} \mathrm{g}^{-1}$, SGR \% day ${ }^{-1}$, Ini Twt -initial total weight (Weight g), Final Twt- final total weight gain. The initial VA content of the fingerling H.longifilis was $30.07 \pm 0.03 \mu \mathrm{g} \mathrm{g}^{-1}$.

\section{DISCUSSION}

The Growth of the African catfish H. longifilis was not enhanced by the addition of proVAC cassava, However there are significant indications based on the results biomass VA, to suggest that VA content of the fish biomass was enhanced. We did not do organ analysis in this research, but homogenous blend of treatment fish were analyzed. The proVAC $\beta$-carotene content of the diets reflected in the VA content of the $H$. longifilis fish biomass. The increasing inclusion of provitamin A cassava ( $0-$ $25 \%$ ) resulted in significantly higher vitamin A content of the fish biomass. This suggests the ability of the catfish to convert the $\beta$-carotene in the cassava to vitamin $A$ in the fish flesh. Channel catfish have been known to convert $\beta$-carotene in plant materials into vitamin $\mathrm{A}[65,66]$. It has been noted that Tilapia can biotransform $\beta$-carotene and canthaxanthing into vitamin $\mathrm{A}_{1}$. Tilapia can also biotransform the dihydroxy carotenoids like astaxanthin, zeaxanthin, luthein and tunaxanthin directly 
into vitamin $\mathrm{A}_{2}$ [37]. Similarly $\mathrm{Hu}$ et al. [67] noted that hybrid Tilapia O. niloticus $\times$ O. aureus has the ability of utilizing $\beta$-carotene to meet their dietary vitamin A (VA) requirement of 5,850 to 6,970 $\mathrm{IU} \mathrm{kg}{ }^{-1}$. Postsmolt Salmon fed with diets that had increasing levels of retinol (6\% to $749 \mathrm{mg} \mathrm{kg}^{-1}$ ) had body VA content that reflected the diet [9]. To the best of our knowledge this will be the first published paper on the African catfish H.longifilis fed with genetically improved proVAC cassava, showing enhanced biomass VA content (provitamin A $\beta$-carotene per feed can be seen in table 2). This suggests also that the fish converted $\beta$-carotene from cassava to vitamin A. The proVAC content of the feed were prevented from degradation through the following processing precautions. The proVAC cssava was not dried outside in the sun but was oven dried to preserve the $\beta$-carotene content of the feed. Drying of proVAC cassava within an oven at a low temperature was to guard against photolysis of the $\beta$-carotene. Oven drying of proVAC cassava ensures up to $91 \%$ carotenoid retention [33]. The high proVAC $\beta$-carotene content of our feed was also maintained by steaming and preconditioning of the ingredient during feed production. Non fermented fufu and garri made from cassava retained $43.6 \%$ and $42.2 \%$ proVAC after processing [68]. However a disadvantage is that during oven-drying, increase in drying temperature is directly leading to an increase in cyanide retention [26, 29]. However in this research cyanogen was very low as $3.08 \%$ (according to our analysis). This may have been because of our combined processing methods for the proVAC cassava before feed production; viz. soaking in water [31], grinding [30,69] and drying steaming and solid state fermentation with $L$. acidophilus [25]. The cassava was not allowed to ferment in all experimental diets except F6. Fermentation affects the proVAC content of the diets as we noted.

Inclusions of the ProVAC cassava in the catfish diet resulted in elevated FCR suggesting poor utilization of the ingredient. African catfish had been reported to utilize carbohydrate very well [51]. It may be that at the size of the catfish (fingerling to post fingerling ) average size $1.69 \pm 0.5 \mathrm{~g}$, it was not able to properly utilize proVAC cassava. This may have caused the elevated FCR. High FCR could be due to increasing inclusion of proVAC cassava and its constituent biochemical. In a previous research elevated FCR had been associated with increasing inclusion of VA in Tilapia [70], in Wuchang bream, [71], and in some feed mixed for gibel carp, [72]. However FCR of the catfish reduced with reduction in the proVAC cassava in our research (Fig.1). There was steady reduction in FCR as $\beta$-carotene inclusion in the diet decreased. Moreover elevated FCR could be because of possible oligosaccharides in the cassava, oligosaccharides have been known to reduce nutritional value of carbohydrate feed [73]. The protein efficiency ratio was best for the fish fed with F4 followed by F5. This could be because of poor protein of the diets and better utilization of lower inclusion levels of proVAC. Madalla [5] noted that cassava root meal was poorly utilized by Nile tilapia.

Excess VA are stored in the liver lipid since VA is oil soluble [68, 74].We noted high HSI as the inclusion level of proVAC cassava increases from 0 to $20 \%$. The body stores excess VA in the liver of fish which contains about $90 \%$ of the total VA [29, 37]. Fish does not synthesize VA and had to obtain it from their diets [74, 75].This is in line with our findings in this research consequently, the lower the dietary VA the lower the HSI and liver lipid. Reduction in the body and liver lipid and the plasma cholesterol contents of fish in response to vitamin A deficiency had been noted by [72]. The lipid storage in the liver could have accounted for the high HSI of the catfish fed with high proVAC cassava diets. Although the liver is main storage organ for VA, some VA storing cell are resident in the intestine, kidney, ovaries, gill and testes of fish [76]. In view of this, we blended the whole fish sample per treatment feed before VA analyses in this research. In the present study, HSI of the catfish increased with dietary inclusion of proVAC cassava.

Vitamin A deficiency had been note to cause reduction in mucous layer of fish that can encourage parasitic attack $[74,75]$. There was parasitic attack on the catfish fed with feed 3 during the experiment. The cause could not be established but it specifically affected the catfish in the treatment. However it is possible that the infection was opportunistic since the research was carried out during dry weather condition in Nigeria noted for elevated water temperature and parasites proliferation.

High inclusion of proVAC in catfish diets caused reduced growth rate this had been noted also for carp fed with high proVAC feed $[72,77]$. ProVAC cassava contain little cyanogen reduced to merely $3 \%$ proVAC cassava production. 
The reason for differences in the gut length is not clear. The reduction in gut length could be due to reactions from intestinal cells to high concentrations of carbohydrate or the $\beta$-carotene vitamin $\mathrm{A}$ precursor. However vitamin A had been noted as an essential nutrient element for maintenance of the functioning and structure of the digestive tract [78]. Hyperavitaminosis of VA has been associated with several health risk like production of excessive extracellular matrix [79] aberrant reproductive complications, and visual impairment $[8,80,81]$ and $[3,67,68]$, pale yellow and fragile livers and reduced hepatosomatic index [54] and vertebral deformities $[9,4]$. We cannot establish the reason for gut length effect but it has also previously been reported that Vitamin A deficiency reduced intestinal fold height in juvenile Jian carp,Cyprinus carpio var. Jian carp [58] and the digestive problems in carp [72]. The reason for the gut length effect in this experiment remains to be fully unraveled. Catfish fed with $0 \%$ proVAC diet did not have any change in their gut length. In a previous experiment, there was no report of gut length changes when tilapia species were fed with cassava [6]. However Tilapia is more herbivorous than facultative carnivore hetero branchus in our experiment. This calls for future research on this issue.

\section{CONCLusions}

The growth and vitamin A status of the African catfish $H$. longifilis were affected by the genetically engineered cassava. The level of vitamin A in the catfish suggests that catfish was able to convert provitamin A $\beta$-carotenoid into vitamin A in the fish. Although vitamin A is stored in the liver, we did not analyze organs. Due to the size of the catfish we homogenized the whole fish before analysis. The growth performances of the fish (SGR, FCR and weight gain) suggest that catfish can tolerate high carbohydrate diets and growth appreciably well. The effect on the gut length is noticeable but the reasons are not clear. This makes it important for more research on this especially as the proVAC is a novel cassava variety and would be consumed by humans.

\section{ACKNOWLEDGEMENTS}

We are grateful for the services of Mr Peter Onah Chief Technologist of the Department of Microbiology Godfrey Okoye University Enugu, Enugu State Nigeria for his cooperation in the Laboratory analysis.

\section{REFERENCES}

[1] Gatlin III, D.M., Barrows, F.T., Brown, P., Dabrowski, K., Gaylord, G.T., Hardy, R.W., Herman, E., Hu, G., Krogdahl, Å., Nelson, R., Overturf, K., Rust, M., Sealey, W., Skonberg, D., Souza, E.J., Stone, D., Wilson, R. \& Wurtele, E. (2007) Expanding the utilization of sustainable plant products in aquafeeds: a review. Aquacult. Res.,38, 551-579.

[2] Hemre G-I, Mommsen T.P., and Krogdahl A.E. (2002) Carbohydrates in fish nutrition: effects on growth, glucose metabolism and hepatic enzymes. Aquaculture Nutrition 2001, 7: 1- 20

[3] Krogdahl Å, G.I Hemre, and T.P. Mommsen (2005) Carbohydrate in fish nutrition: digestion and absorption in post larval stages. Aquaculture Nutrition, 11, 103-122.

[4] Smith, O.B. (1992) A review of ruminant responses to cassava based

[5] diets. In: Hahn, S.K., Reynolds, L. and Egbunike, G.N. ,(Eds.)

[6] Proceedings of the Workshop on the Potential Utilization of Cassava

[7] Madalla N. (2008) Novel Feed Ingredients for Nile Tilapia (Oreochromis niloticus L.). A PhD thesis submitted to Institute of Aquaculture University of Stirling Scotland United Kingdom December 2008

[8] Wee, K.L. and Ng, L.T. (1986) Use of cassava as an energy source in a pelleted feed for the tilapia, Oreochromis niloticus L. Aquaculture Fish Management 17(2), 129-138.

[9] Enyidi, U.D. Pirhonen, J. \& Vielma, J. (2014) Effects of sesame seed meal and bambaranut meal on growth, feed utilization and body composition of juvenile African catfish Clarias gariepinus. Iranian Journal of Fisheries Sciences 13(4)998-1013

[10] NRC, (National Research Council) (2011) Nutrient Requirements of Fish and Shrimp. The National Academy Press, Washington, DC, USA, pp. 186-198. 
[11] Ørnsrud, R., R. E.J. Lock., R WaagbØ, Krossøy, C. \& Fjelldal, P.G. (2013) Establishing an upper level of intake for vitamin A in Atlantic salmon (Salmo salar L.) postsmolts/. Aquaculture Nutrition 19; 651-664.

[12] Nweke, F. (2004) New challenges in the cassava transformation in Nigeria and Ghana (Vol. 118). Washington, D.C: International Food Policy Research Institute.

[13] Heuberger C. (2005). Cyanide content of cassava and fermented products with focus on attiéké and attiéké garba. Diss. ETH No. 16247. Dissertation submitted to the Swiss Federal Institute of Technology, Zurich, for the degree of Doctor of Natural Sciences.

[14] Okigbo, B.N. (1980) Nutritional implications of projects giving high priority to the production of staples of low nutritive quality. In the case for cassava (Manihot esculenta, Crantz) in the humid tropics of West Africa. Food Nutr Bull 2:1-10

[15] FAO (2016) Nigeria at a glance. http://www.fao.org/nigeria/fao-in-nigeria/nigeria-at-aglance/en/. Assessed 27th December 2016

[16] Sheffield, J., Taylor, N., Fauquet, C., \& Chen, S. X. (2006). The cassava (Manihot esculenta Crantz) root proteome: protein identification and differential expression. Proteomics, 6, $1588 \mathrm{e} 1598$.

[17] Montagnac, J.A, Davis C.R. \& Tanumihardjo, S.A. (2009) Nutritional value of cassava for use as a staple food and recent advances for improvement. Compr Rev Food Sci Food Saf 8, 181-194.

[18] Welsch, R., Arango, J., Bar, C., Salazar, B., Al-Babili., Beltran, J., Chavarriaga, P., Ceballos, H., Tohme, J. \& Beyer, P. (2010) Provitamin A Accumulation in Cassava (Manihot esculenta) Roots Driven by a Single Nucleotide Polymorphism in Phytoene Synthase Gene. The Plant Cell, Vol. 22: 3348-3356.

[19] Tewe, O.O \& Lutaladio, N. (2004) Cassava for livestock feed in sub-Saharan Africa. Rome, Italy:FAO.

[20] La Frano M.L., Woodhouse L.R., Burnett D.J. \& Burri J.B. (2013) Biofortified cassava increases $\beta$-carotene and vitamin A concentrations in the TAG-rich plasma layer of American women. British Journal of Nutrition, 110, 310-320.

[21] Ubalua A.O., AND Ezeronye O.U. (2008) Growth responses and nutritional evaluation of cassava peel based diet on tilapia (Oreochromis niloticus) fish fingerlings. Journal; of food technology 6, 207-213.

[22] Dada, A.A., Adeparusi, E.O. and Malomo E.O. (2015). Dietary Utilization of Different Portions of Sweet Cassava Root (Manihot palmata) for the Nile Tilapia Oreochromis niloticus (Linnaeus, 1758) Journal of Fisheries and Aquatic Science, 10: 569-574.

[23] Padua, D.M.C., Silva, P.C., Padua, J.T., Fernandes, C.M., Andrade, M.L. \& Lima, D.A.S. (1998) The nutritive value of cassava (Manihot esculenta) leafs and stem meal in pelleted feed for pacu (Piaractus mesopotamicus). In: Anonymous Aquaculture '98 Book of Abstracts, 15-19 February 1998, Las Vegas, U.S.A., U.S.A: World Aquaculture Society

[24] Gundersen, T.E. \& Blomhoff, R. (2001) Qualitative and quantitative liquid chromatographic determination of natural retinoids in biological samples.J. Chromatogr. A, 935,13-43.

[25] Siritunga, D. \& Sayre, R.T. (2004) Engineering cyanogen synthesis and turnover in cassava (Manihot esculenta). Plant Mol Biol 56:661-9.

[26] Bradbury, J.H. \& Denton, I.C. (2011) Mild methods of processing cassava leaves to remove cyanogens and conserve key nutrients. Food Chem 127, 1755-1759.

[27] Gidamis, A. B, O’Brien, G.M., Poulter, N.H. (1993) Cassava detoxification of traditional Tanzanian cassava foods. Int J Food Sci Technol 28:211-8.

[28] Cooke, R.D. \& Maduagwu, E. (1978) The effects of simple processing on the cyanide content of cassava chips. J Food Technol 13:299-306.

[29] Nambisan, B. \& Sundaresan, S. (1985) Effect of processing on the cyanoglucoside content of cassava. J Sci Food Agric 36:1197-203.

[30] Bradbury, J.H. \& Holloway, W.D. (1988) Cassava, M. esculenta. Chemistry of tropical root crops: significance for nutrition and agriculture in the pacific. Australian Centre for International Agricultural Research, monograph no. 6, Canberra, Australia, p 76-104. 
Growth and Vitamin A Enhancement Effects of Provitamin A ß-Carotenoid Cassava (Manihot Esculanta Crantz) UMUCASS38 (IITA-TMS-IBA0114121), in the Practical Diets of Fingerling of African Catfish Heterobranchus longifilis

[31] Nambisan, B. (1994) Evaluation of the effect of various processing techniques on cyanogen content reduction in cassava. Acta Hortic 375:193-201.

[32] Oke, O.L. (1994) Eliminating cyanogens from cassava through processing: technology and tradition. Acta Hortic 375:163-74.

[33] Westby, A, Choo, B.K. (1994) Cyanogen reduction during lactic fermentation of cassava. Acta Hortic 375:209-15.

[34] Njoku, D. N., V. E. Gracen, C. N. Egesi, I. Asante, S. K. Offei, E. Okogbenin, P, Kulakow, O. N. Eke-okoro. \& Ceballos. H. (2011) Breeding for enhanced $\beta$-carotene content in cassava: Constraints and accomplishments. Journal of Crop Improvement 25:560-571.

[35] De Moura F.F., Moursi, M., Lubowa, A., Ha, B., Boy, E., Oguntona, B, et al. (2015) Cassava Intake and Vitamin A Status among Women and Preschool Children in Akwa-Ibom, Nigeria. PLoS ONE 10(6): e0129436. doi:10.1371/journal.pone.0129436.

[36] WHO (World Health Organization) (2009) Global prevalence of vitamin A deficiency in populations at risk 1995-2005. In WHO Global Data-base on Vitamin A Deficiency. (Geneva, Switzerland: World Health Organization) of carotenoids. Trends Plant Sci.10:178-186.

[37] Sayre, R., Beeching, J.R, Cahoon, E.B, et al. (2011) The bio-cassava plus program: biofortification of cassava for sub-saharan Africa.Annu Rev Plant Biol62, 251-272.

[38] Moise, A.R., von Lintig, J. \& Palczewski, K. (2005) Related enzymes solve evolutionarily recurrent problems in the metabolism of carotenoids. Trends Plant Sci.10:178-186.

[39] Katsuyama, M. \& Matsuno T. (1988) Carotenoid and vitamin A and metabolism of carotenoids, beta-carotene,canthaxanthin, astaxanthin, zeaxanthin, luthein and tunatunaxanthin in tilapia Tilapia nilotica. Comp. Biochem. Physiol.90B:134-139.

[40] La Frano M.L., Woodhouse L.R., Burnett D.J. \& Burri J.B. (2013) Biofortified cassava increases $\beta$-carotene and vitamin A concentrations in the TAG-rich plasma layer of American women. British Journal of Nutrition, 110, 310-320.

[41] De Moura, F.F., Moursi, M., Angel, M.D., Angeles-Agdeppa, I., Atmarita A., Gironella, G. M., Muslimatun, S. \& Carriquiry A. (2016) Biofortified b-carotene rice improves vitamin A intake and reduces the prevalence of inadequacy among women and young children in a simulated analysis in Bangladesh, Indonesia, and the Philippines. Am $\mathrm{J}$ Clin Nutr doi: 10.3945/ajcn.115.129270.pg. 1-7.

[42] Chhay Ty., Khieu B., Noy S., Preston T. R. and T. M. Aye (2010) Effect of sun-dried and fresh cassava leaves on growth of tilapia (Oreochromis niloticus) fish fed basal diets of rice. In Livestock Research for Rural Development •March 2010

[43] Tyska, D., MallmannI C.A., CorrêiaII V., Tamiosso C.D., Mallmann A.O., and Neto J.R. (2013) Vegetable Protein concentrates in the diet of South American catfish Rhamdia quelen. Ciência Rural, Santa Maria V43 (7) 1251-1257.

[44] Siqueira, E.M., Arruda, S.F, de Vargas, R.M., de Souza, E.M.T. (2007) $\beta$-Carotene from cassava (Manihot esculenta, Crantz) leaves improves vitamin A status in rats. Comp Biochem Physiol Part C 146:235-40.

[45] Saltzman, A, Birol, E., Bouis, H.E, Boy, E., De Moura F.F, Islam, Y. \& Pfeiffer, W. (2013) Biofortification: progress toward a more nourishing future. Glob Food Secur 2013; 2:9-17.

[46] Rodriguez-Amaya, D.B. (1999) Carotenoides y preparación de alimentos: la retención de los carotenoides provitamina A en alimentos preparados, procesados almacenados. Washington, D.C.: USAID/JSI, 1999. 105 p. (OMNI Project).

[47] Tacon, A.G.J. Nutritional fish pathology. Rome: FAO, (1992). (FAO Fisheries Technical Paper, 330) 75p.

[48] Rando R. R. (1990) The chemistry of vitamin A and vision. Angew. Chem. Int. 1990:461-480.

[49] West C. E. Rombout J. M. Van der Ziypp A. J. Siytsma S. R. (1991) Vitamin A and immune function. Proc. Nutr. Soc. 1991:251-262.

[50] Ufodike, E.B.C. \& Matty, A.J. (1984) Nutrient digestibility and growth responses of rainbow trout (Salmo gaidneri) fed to different levels of cassava and rice.Hydrobiologia 119 (2):83-88. 
[51] Nieves, P. \& Barro, R. (1996) Evaluation of local ingredients (fish, shrimp, snail, copra, leaf meals and rice bran) for feeding Nile tilapia (Oreochromis niloticus) fingerlings. In: Santiago, C.B., Coloso, R.M., Millamena, O.M. \& Borlongan, I.G., (Eds.) Proceedings of the National Workshop on Fish Nutrition and Feeds, 1-2 June 1994, Iloilo, Philippines, Iloilo, Philippines: Southeast Asian Fisheries Development Centre, (SEAFDEC).

[52] Borlongan, I.G. \& Coloso, R.M. (1994) Leaf meals as protein sources in diets for milkfish Chanos chanos (forsskal). In: De Silva, S.S., (Ed.) Fish Nutrition Research in Asia: Proceedings of the 5th Asian Fish Nutrition Workshop, January 1993, Udorn Thani, Thailand Manila, Philippines: Asian Fisheries Society.

[53] Ali, M.Z. \& Jauncey, K. (2004) Optimal dietary carbohydrate to lipid ratio in African catfish Clarias gariepinus (Burchell 1822) Aquaculture International (2004) 12: 169. doi:10.1023/B:AQUI.0000032065.28059.5b.

[54] Wilson, R.P. (1994) Utilization of Dietary Carbohydrate by Fish. Aquaculture, 124, 67-80. http://dx.doi.org/10.1016/0044-8486 (94)90363-8.

[55] Li, J.H., Ma, L., Cheng, Z.Y., Bai, D.Q., Qiao, X.T. \& Sun, J.H. (2015) The Effects of Growth Performance and Organosomatic Indices of Atlantic Salmon Juvenile by Using Different Carbohydrate-to-Lipid Ratios in Feeds. World Journal of Engineering and Technology, 3, 24-29. http://dx.doi.org/10.4236/wjet.2015.34C003

[56] Hilton, J.W. (1983) Hyper vitaminosis A in rainbow trout (Salmo gairdneri): toxicity signs and maximum tolerable level. J. Nutr., 113, 1737-1745.

[57] Saleh, G., Eleraku, W. \& Gropp, J.M. (1995). A short note on the effects of vitamin A hypervitaminosis on health and growth of Tilapia nilotica (Oreochromis niloticus). Journal of Applied Ichthyology, 11, 382-385.

[58] Ørnsrud, R., Graff, L.E., Høie, S., Totland, G.K. \& Hemre, G.I. (2002) Hypervitaminosis A in first-feeding fry of the Atlantic sal-mon (Salmo salar L.).Aquac. Nutr., 8,7-13.

[59] Villeneuve, L.A.N., Gisbert, E., Moriceau, J., Cahu, C.L., Zambonino, J.L., 2006. Intake of high levels of vitamin A and polyunsaturated fatty acids during different developmental periods modifies the expression of morphogenesis genes in European sea bass (Dicentrarchus labrax). Br. J. Nutr. 95, 677-687.

[60] Yang, Q.H., Zhou, X.Q., Jiang, J. \& Liu, Y., (2008) Effect of dietary vitamin A deficiency on growth performance, feed utilization and immune responses of juvenile Jian carp (Cyprinus carpiovar. Jian). Aquac. Res. 39, 902-906.

[61] Martinez, G.M., Baron, M.P. \& Bolker, J.A. (2007) Skeletal and pigmentation defects following retinoic acid exposure in larval summer flounder, Paralichthys dentatus. J. World Aquac. Soc, $38,353-366$.

[62] Fernández, I. \& Gisbert, E., (2011)The effect of vitamin A on flatfish development and skeletogenesis. Aquaculture 315, 34-48.

[63] Parrish, C.C. (1999) Determination of total lipid classes and fatty acids in aquatic samples. In: Wetzel RG, Art MT, Wainmann BC (ed) Lipids in Freshwater Ecosystems. Springer-Verlag, New York, NY, USA pp 4-20.

[64] Kainz, M. \& Arts, M., Mazumder, A. (2004) Essential fatty acids in the planktonic food we and their ecological role for higher trophic level. Limnol Oceanogr 49: 1784-1793

[65] Wheeler, E.L. \& Ferrel, R.E. (1979) A method for phytic acid determination in wheat and wheat fractions. Cereal Chem., 48: 312-320.

[66] Fukushima, A.R., Nicoletti, M.A., Rodrigues, A.J., Pressutti, C., Almeida, J., Brandão, T., Ito, R.K., Leoni, L.A.B. and De Souza Spinosa, H. (2016) Cassava Flour: Quantification of Cyanide Content. Food and Nutrition Sciences, 7, 592-599. http://dx.doi.org/10.4236/fns.2016.77060

[67] Lee, C.M. (1987) Carotenoids in cultured channel catfish. PhD dissertation. Auburn University, Auburn Alabama USA

[68] Lee, C.M, Boileau, A.C, Boileau, T.W, et al. (1999) Review of animal models in carotenoid research. J Nutr 129, 2271-2277. 
[69] Hu, C.J.; Chen, S.M.; Pan, C.H. \& Huang, C.H. (2006) Effects of dietary vitamin A or $\beta$ carotene concentrations on growth of juvenile hybrid tilapia, Oreochromis niloticus x $O$. aureus. Aquaculture, 253, 602-607,

[70] La Frano M.R. \& B.J. Burri (2014) Analysis of retinol, 3-hydroxyretinol and 3,4didehydroretinol in North American farm-raised freshwater fish liver, muscle and feed. Aquaculture Nutrition. 20, (6), 722-730

[71] Cardoso, A.P., Mirione, E., Ernesto, M., Massaza, F, Cliff, J., Haque, M.R, Bradbury, J.H. (2005) Processing of cassava roots to remove cyanogens. J Food Comp Anal 18:451-60.

[72] Campeche, D.F.B., Catharino, R.R., Godoy, H. T. \& Cyrino, J.E.P . (2009) Vitamin A in diets for Nile tilapia . Sci. Agric. (Piracicaba, Braz.), 66, (6) 751-756.

[73] Liu B.O., Zhao Z., Brown P.B., Cui H., Xie J., Habte-Tsion H-M \& Ge X. (2016) vitamin A requirement of juvenile Wuchang bream (Megalobrama amblycephala) determined by growth and disease resistance. Aquaculture 450 (2016) 23-30.

[74] Shao, L., Zhu X., Yang Y., Jin J., Liu H., Han D,. \& Xie, S. (2016). Effects of dietary vitamin A on growth, hematology, digestion and lipometabolism of on-growing gibel carp (Carassius auratus gibelio var. CAS III) Aquaculture 460, 83-89

[75] Glencross, B.D., Boujard, T. \& Kaushik, S.J. (2003) Influence of oligosaccharides on the digestibility of lupin meals when fed to rainbow trout, Oncorhynchus mykiss. Aquaculture 219: 703-713.

[76] NRC, (National Research Council) (1993) Nutrient requirements of fish. National Academy press, Washington, DC, $114 \mathrm{p}$

[77] Blomhoff, R., M.H. Green \& Norum, K.R (1992) Vitamin A: Physiological and biochemical processing, Annu Rev. Nutr. 12, 37-57.

[78] Blomhoff R, Wake K. 1991. Perisinusoidal stellate cells of the liver: important roles in retinol metabolism and fibrosis. FASEB J 5:271-277.

[79] Lu, K.L., Xu, W.N., Li, J.Y., Li, X.F., Huang, G.Q., Liu, W.B., (2013) Alterations of liver histology and blood biochemistry in blunt snout bream Megalobrama amblycephala fed high-fat diets. Fish. Sci. 79, 661-671.

[80] Reifen, R., Zaiger, G., Uni, Z., (1998). Effect of vitamin A on small intestinal brush border enzymes in rat. Int. J. Vit. Nutr. Res. 68, 281-286

[81] Nollevaux, M.C., Guiot, Y., Horsmans, Y., Leclercq, I., Rahier, J., Geubel, A.P. \& Sempoux, C. (2006) Hypervitaminosis A-induced liver fibrosis: stellate cell activation and daily dose consumption. Liver Int., 26, 182-186.

[82] Grisdale-Helland, B., Helland, S.J. \& Asgard, T. (1991) Problems associated with the present use of menadione sodium bisulfate and vitamin-A in diets for Atlantic salmon. Aquaculture, 92, 351-358.

[83] Lewis-McCrea, L.M. \& Lall, S.P. (2010) Effects of phosphorus and vitamin C deficiency, vitamin A toxicity, and lipid peroxida-tion on skeletal abnormalities in Atlantic halibut (Hippoglossus hippoglossus).J. Appl. Ichthyol., 26, 334-343 